\title{
線路分岐と配電線䛪導雷現象
}

$\begin{array}{llll}\text { 正員 } & \text { 道下 } & \text { 幸志 } & \text { (静岡大学) } \\ \text { 正員 } & \text { 石井 } & \text { 勝 } & \text { (東京大学) } \\ \text { 正員 } & \text { 本拫 } & \text { 保二 } & \text { (東北電力) }\end{array}$

\section{Lightning-Induced Voltage on Power Distribution Line Having a Branch}

Koji Michishita, Member (Shizuoka University), Masaru Ishii, Member (The University of Tokyo), Yasuji Hongo, Member (Tohoku Electric Power Co.)

The lightning-induced voltage on power distribution line having a branch is studied based on numerical calculations. The induced voltage is calculated by the method where the tangential component of the electric field to the line is looked upon as inducing sources, and the electric field is calculated by decomposing the lightning channel into numerous dipoles. Accuracy of the calculated result is ensured with experimental result obtained by using a reducedscale model. The induced voltage on the distribution line turns out to be influenced by its branch, and is found to be dependent not only on the configuration of a branch line but also on the location of the lightning striking point. In most of the cases, the induced voltage increases when a branch is connected to the distribution line

キーワード：雷，大地導電率，誘導雷サージ，水平電界，垂直電界

\section{1. はじめに}

配電線，通信線等に生じる誘導雷現象に効率的な対策を 施すためには，誘導雷電圧に影響を及ぼす要因を正確に把 握する必要がある。近年では，大地導電率(1-8) や雷放電路 の傾き(8-10)が誘導雷現象に及ぼす影響が注目を集めている。 大地導電率は, 水平方向の電界（以下，水平電界と表記 する）に大きく影響を及ぼすために，水平電界を起誘導源 とする誘導雷現象も大地導電率の影響を大きく受けること が明らかにされている(3,8)。雷道が大地に垂直で，大地導 電率が有限な場合には，誘導雷電圧の雷揧点方位への依存 性が大地が完全導体の場合とは大きく異なり，有限長線路 の一端の誘導雷電圧は，雷撃点までの距離が等しい場合， 線路の延長線上に雷撃があった場合に最も大きくなること が示されている(3)。

配電線に生じる誘導雷電圧現象は，大地導電率や雷放電 路の傾きを含めた雷放電路モデルの他に，線路終端点や分 岐線など線路構成要素の影響も受ける。線路の終端条件が 誘導雷現象に及ぼす影響については検討が行われているも のの (7.11)，線路分岐が誘導雷現象に及ぼす影響については 検討例が無く，その詳細は明らかにされていない。現実の 配電線は複雑に分岐しており，分岐線をもつ配電線に生じ る誘導雷現象を検討しておく事は，配電線の設計を考える 上では必須である。

本論文では，水平電界を考虑した配電線誘導雷電圧解析 手法(12)により，雷道が大地に垂直な場合の配電線誘導雷現
象に線路分岐が及ぼす影響について論じる。また，計算結 果の妥当性について，縮小モデルを用いた実験結果と比較 することにより示す。

\section{2. 解析手法}

$\langle 2.1\rangle$ 電界計算手法 電界の計算に当たっては, 雷放 電路を微小な双極子に分割し, 各双極子の複素振幅を雷放 電路モデルに従って計算する。次に，各双極子の生じる電 界をNorton解(13) 用いて求め，乙九らの和をとる事に上り 架間の任意の点における電界を周波数領域で求め，さらに それらを逆フーリエ変換して時間領域の解を得た(3)。電界 の計算手法は文献 (3) と全く同一である。電界の計算例につ いては文献(3)を参照されたい。

〈2.2〉誘導雷電圧計算手法 誘導雷電圧の計算は, 水 平電界を考虑した配電線誘導雷電圧解析手法により行った。 大地に水平な線路には水平電界が進行波電流を誘起し, 分 圧器接続点など大地に垂直な導体には垂直電界が進行波電 流を誘起する(14)。従って，計算では全線路にわたっての線 路の接線方向の電界の計算が必要となり，さらに誘導雷電 圧を求める際には大地に水平な線路であっても垂直電界の 計算が必要となる。本手法により計算される分岐のない算 導線路に生じる誘導雷電圧波形が，大地導電率や雷放電路 の傾きにかかわらず妥当である事は，縮小モデルを用いた 実駼結果と比較することにより確かめられている(5,7,8,10)。

分岐線が基幹配電線に垂直に接続されている場合には, 分岐線および基幹配電線に生じた進行波は, 線路分岐点に 
おいてのみ結合する。このため，線路分岥が配電線誘尊雷 電在に及ぼ寸影響は, 線路分岐点に流入才る進行波電流の 和が○であるという条件で計算することができる。

このほかの誘導雷電圧の計算手法は，文献(7) と全く同一 である。

\section{3. 英呀との比较による計算結果の妥当性の検証}

〈3.1〉縮小モデル実験実験は，東北電力湖仙台中山 野球グラウンドにおいて行った。

図 1 に模擬雷撃点，模擬分岐線，及び模擬基幹配電線の 平面図を示す。縮小率は1/20とし，モデル基幹配電線は、 地上高 $10 \mathrm{~m}$, 直径 $10 \mathrm{~mm}$, 長さ $500 \mathrm{~m}$ 相当, 実高, 実径, 実長は 各々0. $5 \mathrm{~m} ， 0.5 \mathrm{~mm}, 25 \mathrm{~m}$ である。モデル分岐線は地上高 $10 \mathrm{~m}$ ， 直径 $10 \mathrm{~mm}$ ，長さ100m相当であり，実礐は $5 \mathrm{~m}$ である。模擬分 岐線の一端は模擬基幹配電線にほほ直角に，その中間点に 接続し，模擬分岐線路のもう一端と，模擬基幹配電線の雨 端は，400ロの抵抗で終端した。これらの終端点における接 地抵抗は約 $40 \Omega$ である。分岐線の有無，及び線路分岐点位 置が基幹配電線誘導雷電压に及ぼす影響を検討するために, 図 1 の例の他に，分岐線が接続されていない場合と，長さ $5 \mathrm{~m}$ 分淮線が図 $10 \mathrm{R}$ 点から $2.5 \mathrm{~m}$ の点で模擬基幹配電線に 直角に接続されている場合の実験も行った。いすれの場合 にも，誘遒電圧の测定は，入力容量約 $10 \mathrm{pF}$ 高インビーダ ンスプローブを用いてR点で行った。電王プロープの周波 数帯域はDC〜100MHzである。

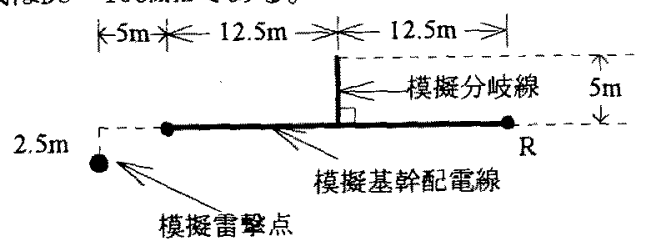

図 1 模擬雷撃点上模擬配電楾の平面図

Fig.1. Plan veiw of a simulated lightning striking point and a simulated overhead wire with a branch line at the center.

大地に垂直な模擬雷道は，文献(7) と同様に，長さ $2 \mathrm{~m} の$ ベーク棒に螺旋状に巻きつけた直径0.5mmの銅線により模揬 した。このベーク棒を12本連結し，一端を大地から $2 \mathrm{~cm}$ 程度 浮加せて固定し、もう一端は気球によりつりさげた。パル ス電流は，大地面に近い一端からもう一端に向かって進行 するように設定されている。模擬雷道の上端は開放端と なっており，雷道上を進行した電流はここで反射される。 䅦擬雷道電流波形は, $8.5 \mathrm{kHz} \sim 100 \mathrm{MHz}$ の周波数帯域を持つ 電流プローブを用いて大地面付近で測定した。

得られた模擬雷道電流波形，およびモデル配電線誘導電 生波形は, $\mathrm{DC} \sim 30 \mathrm{MHz}$ の周波数帯域を持つオプトリンクによ り測定端まで転送され，8ビットの分解能を持つディジタ イザによりサンプル時間閒隔5nsで記録される。

〈3.2〉実験結果と計算結果の比較誘遒電圧の計算に は，模擬雷道電流の测定結果 $(7,15)$ を折れ線近似したものを
用いた。罒2に計算に用いた電流波形を示す。図2に示す模 擬雷電流波形が大地から垂直方向に $120 \mathrm{~m} / \mu \mathrm{s}^{(7.15)}$ で減衰な く伝搬すると仮定して誘導電圧の計算を行い，模擬雷電流 が模擬雷道の上端に達する以前の波形を検討対象とした。

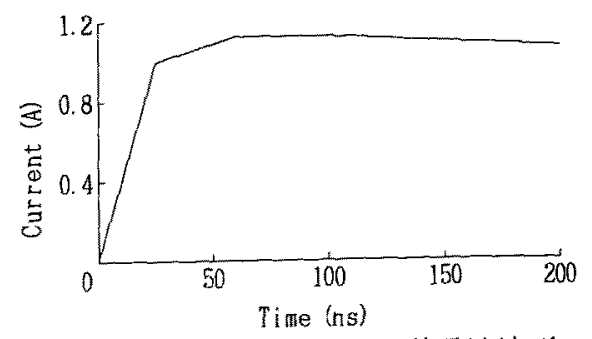

図 2 解析に用いた模擬雷道電流波形

Fig. 2. Current waveform used in the analysis.

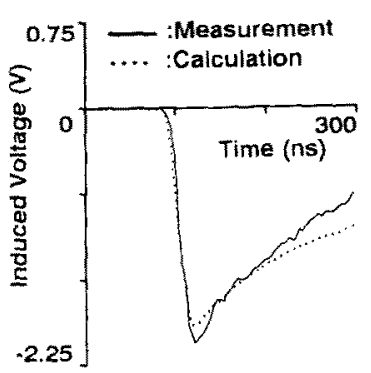

(a) 分岐線がない場合の誘導雷電玨波形

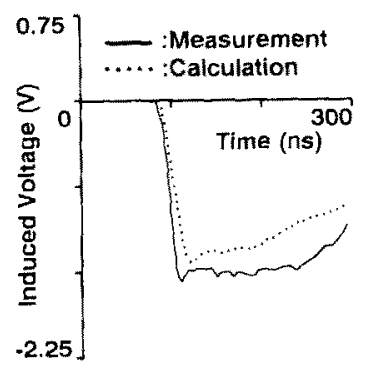

(b) 分岐点が線路中間点にある場合の誘導雷電圧波形

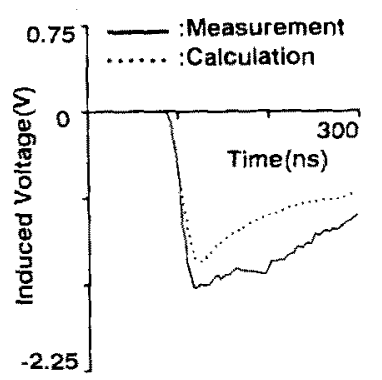

(c) 分岐点がR点から $2.5 \mathrm{~m} に$ にる場合の誘導雷電圧波形

図 3 線路分岐がない場合 $(\mathrm{a})$ ，および分岐線が線 路右端（R点）加ら12.5m(b)及び2. $5 \mathrm{~m}$ (c) の位置に 接続されている場合の線路右端の誘導電纴波形測 定結果上部算結果（大地導電率 $\sigma: 0.03 \mathrm{~S} / \mathrm{m}$ )

Fig. 3. Measured induced voltage waveform at Point $R$ of the trunk line without a branch(a), and those influenced by the $5 \mathrm{~m}$-long branch line at $12.5 \mathrm{~m}(\mathrm{~b})$ and $2.5 \mathrm{~m}$ (c) from Point $\mathrm{R}$, together with calculated waveforms for the ground conductivity of $0.03 \mathrm{~S} / \mathrm{m}$. 
測定点近傍の誘導雷現象に影響を及ぼす周波数帯域の大地 導電率は0.03S $/ \mathrm{m}$ と推定されている(8)。

図 3 (a)に分岐線がない場合, 図 3 (b)，(c)に長さ5mの分 波線がR点から $12.5 \mathrm{~m}$ 及び $2.5 \mathrm{~m}$ の模擬配電線上の点に直角に 接続された場合に，線路右端で測定された誘導電圧波形， および大地導電率を0.035/mとして計算した波形を各々示す。 電圧プローブの入力容量や接地抵抗を考虑して誘導電压の 計算を行い，测定結果との比較を容易にするために，测定 系の周波数帯域を考慮した補正を行っている。図 $3(b) \sim$ (c)の分岐線がある場合の誘導電圧は, 図 $3(\mathrm{a})$ の分岐線が ない場合の測定結果と比較して正の誘導電圧が重畳してい る。分畦線がR点の誘導電圧に及ぼす影響は，それが線路 右端に近い点に接続されている場合の方が若干大きい。実 測されたピーク值で比較すると, 図 3 (b), (c)では, ない 場合に比べてそれぞれ78\%，74\%，計算結果ではこれらの值 がそれぞれ74\%，70\%であり，実測結果と計算結果のピーク 值の相違は5\%程度である。図 $3(\mathrm{a}) \sim(\mathrm{c})$ の誘導電圧波形の 波尾部分については両者に相違が認められる。これは，場 所により異なる大地導電率(7)や大地導電率の周波数依存性 のために，水平電界と模擬線路の進行波が影響を受け，こ の影響が波尾部分において大きかったためと考えられる。

\section{4. 解析モデル}

図 4 に従って，基幹配電線と分岐線および雷撃点との相 対的な位置関係を表記する。長さ $500 \mathrm{~m}$, 地上高 $10 \mathrm{~m}$, 直径 $5 \mathrm{~m}$ の基幹配電線は $\mathrm{x}$ 軸上に位置し, 線路の雨端はサージィ ンピーダンス $(540 \Omega)$ で終端されている。基幹配電線と直角 に接続された分岐線の地上高および直径は基幹配電線と同 一とし，長さを1b，基幹配電線との接続位置を基幹配電線

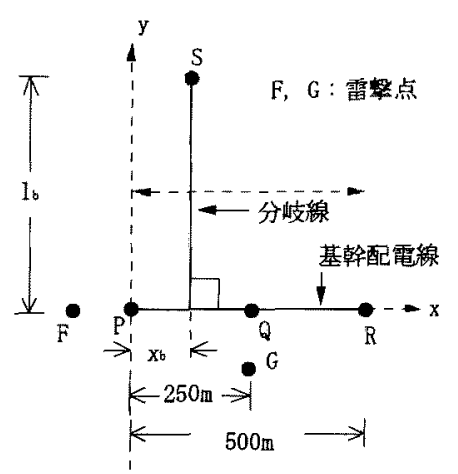

図4 基幹配電線と分岐線及び雷撃点の位置関係

Fig. 4. Arrangement of the overhead wire with a branch, and the lightning striking points.

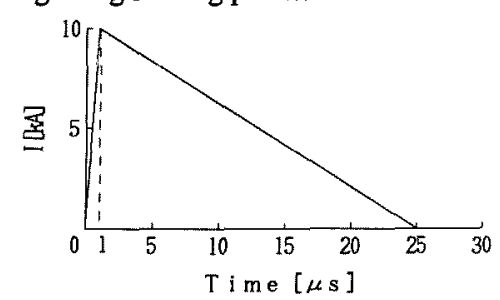

図 5 仮定した㴆還雷撃電流波形

Fig.5 Assumed return-stroke current waveform. 左端からの距離xbで表す。実際の配笔系統においては分岐 線の一端は実質的に開放端とみなせる事から，S 点が開放 の場合の誘導雷電圧の計算を行った。

図4のF 点(基幹配電線の延長上の点)およびG 点（基幹 配電線の線路両端からの距離が等しい点) は雷慗点を表し, 基幹配電線上の距䧺をdで表す。帰還雷整流波形は図 5 に示す三角波で近似し，雷電流は大地面から垂直方向に $100 \mathrm{~m} / \mu \mathrm{s}$ で減衰なく伝搬するものと仮定した。

\section{5. 分岐のある配電線に生じる誘道雷電生波形の特徵}

〈5.1〉分岐線が誘道雷電圧に及ほすす影辢の分類帰還 雷撃により分岐線上に誘起された進行波は，分岐点より基 幹配電線に進入する。この進行波は雷撃点と分岐線との相 対的な位置関係, 分岐線路長, 大地導電率, 線路終端条件 の影響を受ける。また，分岐点では線路定数の不連続に起 因した反射が発生するため，基幹配電線上を伝搬する進行 波も，分岐線接続点位置の影響を受ける。前述したように， 分岐線の一端は実質的に開放端であるため，分岐線では多 重反射が発生する。この反射は，分岐線が基幹配電線上の 誘導雷に及ぼす影響を一層複雑なものとする。

結局, 分岐線が基幹配電線誘導雷電圧波形に及ぼす影響 は分岐点加ら基幹配電線に侵入する進行波によって表され， 影響の度合はこの進行波の大きさと到来時間遅れに大きく 依存する。

〈5. 2〉重盢する電圧波形の到来時間遅れの影響 図 6 に, 雷慗点が図 3 の Fで，雷撃点と基幹配電線との距離 $\mathrm{d} か ゙ ~ 100 \mathrm{~m}$, 大地導電率が $1 \mathrm{mS} / \mathrm{m}$ 場合の $\mathrm{P}$ 点の誘遒雷電圧波形を示す。

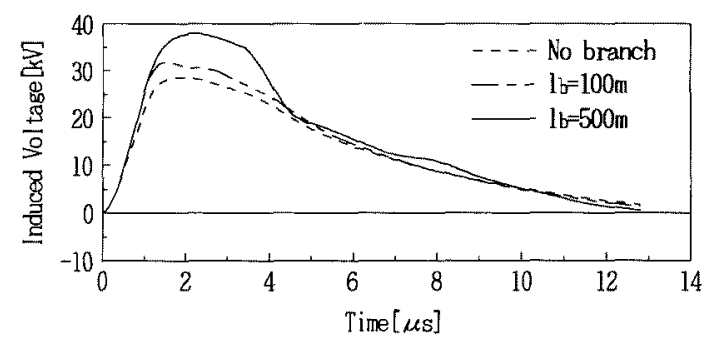

(a) $\mathrm{xb}=50 \mathrm{~m}$.

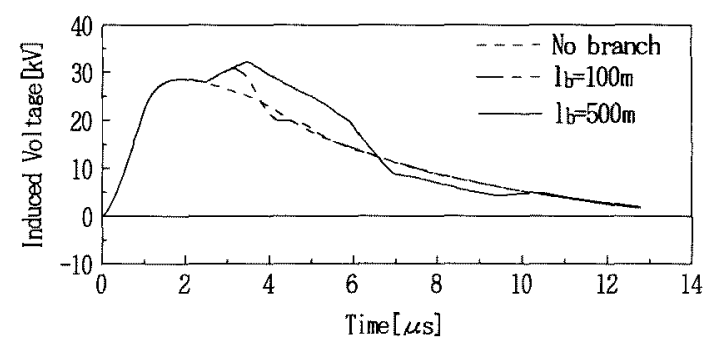

(b) $\mathrm{xb}=350 \mathrm{~m}$

図 6 分岐点が線路左端から $50 \mathrm{~m}(\mathrm{a})$ 及び $350 \mathrm{~m}(\mathrm{~b}) の$ 場合のP点の誘導雷電圧波形

(雷撃点位置 : F, $\mathrm{d}=100 \mathrm{~m}, \quad \sigma=1 \mathrm{mS} / \mathrm{m}$ )

Fig. 6. Lightning-induced voltage waveforms at Point $P$ of the trunk line having a branch line at $x b=50 \mathrm{~m}(\mathrm{a})$ and at $x b=350 \mathrm{~m}(b)$, associated with a return stroke at Point $F$ of $100 \mathrm{~m}$ away. The ground conductivity is $1 \mathrm{mS} / \mathrm{m}$. 
線路分岐点位置は線路左端から50mおよび $350 \mathrm{~m}$ 場合につい て，分岐線路長が $100 \mathrm{~m}$ ，及び $500 \mathrm{~m}$ の時の波形を，分岐線が ない場合と共に示す。

分岐線接続点がP点近傍の場合には，注入される進行波 電圧の極性は正で，分岐線がない場合のP 点の誘導雷電死 波形にほぼ時間遅れなく重疊するため, 図 6 (a)の計算例の ように誘導雷電圧波形は単一のピークをもつ。雷撃点が $\mathrm{F}$ 点の場合には，分岐線の影響が $\mathrm{P}$ 点に到来するには，電磁 波が $\mathrm{P}$ 点から線路分岐点まで伝搬する時間の 2 倍の時間が 必要となる。このため，分岐線接続点が $\mathrm{P}$ 点から離れてい る場合には，P点の誘導雷電圧波形は複数のピークをもち， 図 6 (b)の場合には，遅れて発生する2番目のピークが最初 のピークよりも大きくなっている。いずれの場合にも分岐 線路長が長くなると，分岥線があるために重畳する進行波 の波高値は大きくなっている。

〈5.3〉重量する進行波の強度図7に, 雷撃点が図 4 のGで基幹配電線との距離 $\mathrm{d}$ が $2 \mathrm{~km}$ 場合に，分岐線が接続 された基幹配電線路中間点（Q点）における誘導雷電圧波 形を示す。大地導電率は，図 7 (a)では $1 \mathrm{mS} / \mathrm{m}$, 図 7 (b)では のである。

図 7 の場合の基幹配電線之雷撃点の位㯰関係では, 分岐 線がない場合の誘導雷電圧波形への大地導電率の影響は極 めて小さい。これは，大地導電率の影響を大きく受ける水 平電界が基幹配電線の誘導雷電圧発生にほとんど静与して いないためである。雷撃点と観測点との距離が $2 \mathrm{~km}$ と大きい

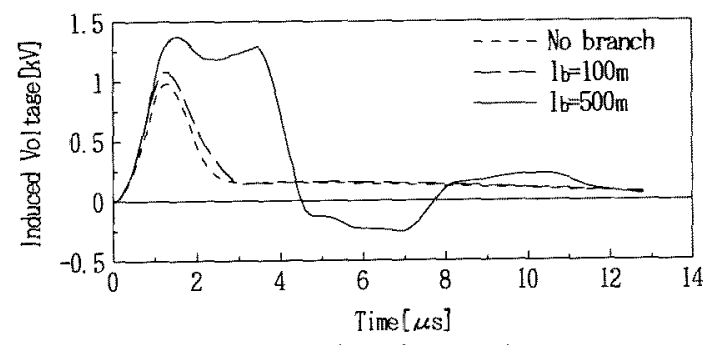

(a) 大地導電率: $1 \mathrm{mS} / \mathrm{m}$.

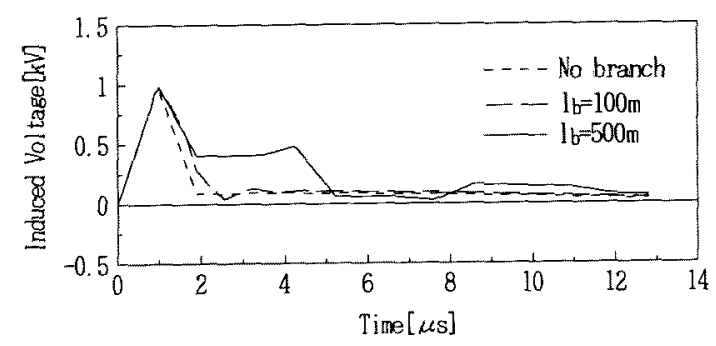

(b) 大地導電率: $\infty$

図 7 大地導電率が $1 \mathrm{mS} / \mathrm{m}(\mathrm{a})$ およびゅ(b)の場合 のQ点の誘導雷電压波形（雷撃点位置： $\mathrm{G}$, $\mathrm{d}=2 \mathrm{~km}, \quad \mathrm{x} b=250 \mathrm{~m})$

Fig. 7. Lightning-induced voltage waveforms at Point $Q$ of the trunk line having a branch line at $x b=250 \mathrm{~m}$, associated with a return stroke at Point $G$ of $2 \mathrm{~km}$ away. The ground conductivity is $1 \mathrm{mS} / \mathrm{m}$ (a) and $\infty$ (b), respectively.
場合には，水平電界において，有限な大地導電率のために 発生子る水平電界成分が支配的となっている(3)。この成分 は，分岐線上では強度の大きい進行波を誘起するために， 分岐線が長い場合の図 7 の波形は，大地導電率の影響を大 きく受けている。

\section{6. 分岐線が基幹配電線誘導雷電圧に及ぼす影曗}

図8k雷撃点が図40F点の場合の, P 点の誘導雷電圧 の分岐線接続位置及び分岐線路長への依存性を示す。

分岐線が接続された場合には，P点の誘導雷電圧は增大 し，分岐線が長いほどこの傾向は顕著となる。 $\mathrm{d}=100 \mathrm{~m} ゙$ l $b$ が500m以上の場合には，S点からの反射波が電圧波形の ピークよりも遅れてP点に到達するために，P点の誘導雷 電圧波高値には影響しなくなる。この時の誘導雷電圧は分 岥線がない場合と比較して最大 $30 \%$ 程度增大寸る。

$1 \mathrm{~b}$ が500m以上で大地導電率が $1 \mathrm{mS} / \mathrm{m}$ の場合には， $\mathrm{d}=100 \mathrm{~m}$ はP点の誘導雷電压は分岐点が $P$ 点に近づくほど, $d=2 \mathrm{~km}$ は線路分岥点がR点に近づくほど増大する。 $\mathrm{d}=100 \mathrm{~m}$ の場合 には大地が完全導体の場合にも登生する水平電界成分が， $\mathrm{d}=2 \mathrm{~km}$ の場合には大地導電率が有限であるために発生する水

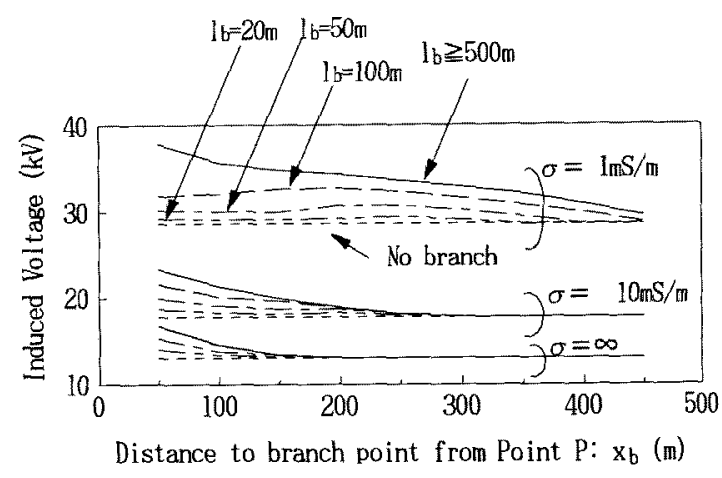
(a) $d=100 m$

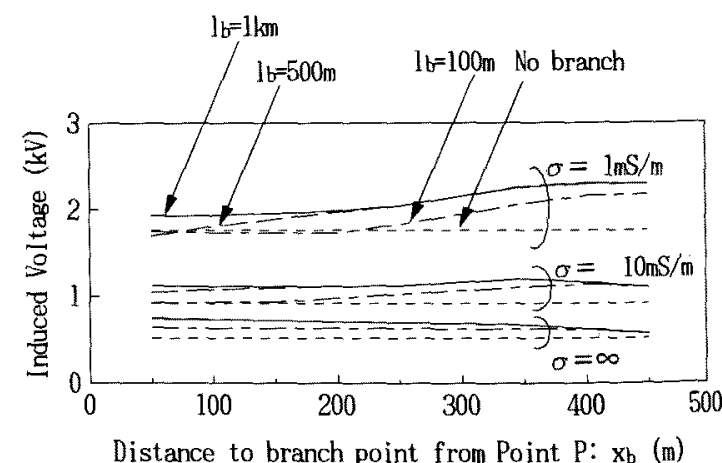

(b) $\mathrm{d}=2 \mathrm{~km}$

図 8 雷揧点までの距離が $100 \mathrm{~m}(\mathrm{a})$ 及び $2 \mathrm{~km}(\mathrm{~b}) の$ 場合のP点の誘導雷電圧波高值の分岐線路長およ び分岐点位置への依存性（雷撃点位置：F）

Fig. 8. Lightning-induced voltage at Point $\mathrm{P}$ of the overhead wire having a branch, associated with a return stroke at Point $F$ at the distance of $100 \mathrm{~m}$ (a) and $2 \mathrm{~km}$ (b), respectively. 
平電界成分が，観測される水平電界において支配的となり， それぞれの成分による誘導雷電圧の発生様相が異なること が，その原因である。 $\mathrm{d}=2 \mathrm{~km}$ でも大地導電率が大きくなると， $\mathrm{d}=100 \mathrm{~m}$ ときと相反するような傾向は見られない。

図 9 に, 雷撃点が図 4 の G 点で雷揧点までの距傩が $100 \mathrm{~m}$ の場合の，基幹配電線路中間点（Q点）の誘導雷電圧の分 岐線路長及び分岐点位置への依存性を示す。この場合には， 線路分岐がQ点の誘導雷現象に及ぼす影響は小さく, 大地 導電率にかかわらずその影響の度合は最大10\%程度である。

図 9 では, 分㞳点がQ点近傍で分岐線が短い場合に, 誘 導雷電圧はわずかに大きくなっている。これは分岐線末端 における反射のためであり, 分岐線が長くなり反射のQ点 への到来が遅れた場合には，Q点の誘導雷電圧は若干減小 している。

図10に，他の条件が図 9 と同じで, 雷撃点までの距離が

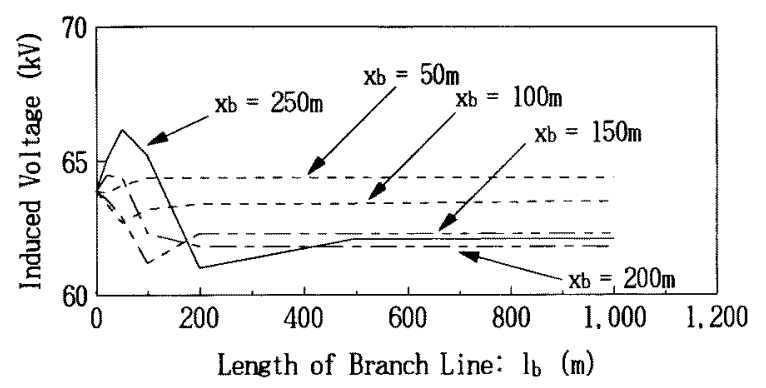

(a) 大地導電率 $(\sigma): 1 \mathrm{mS} / \mathrm{m}$

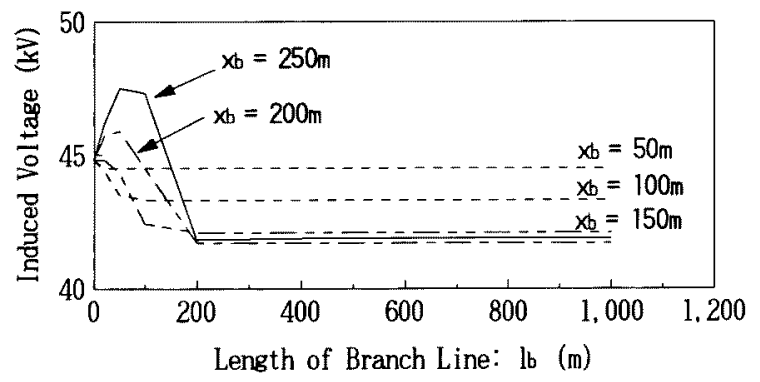

(b) 大地導電率 $(\sigma): 10 \mathrm{mS} / \mathrm{m}$

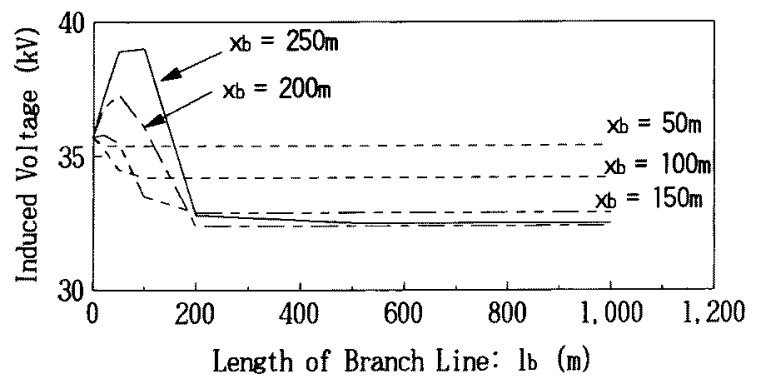

(c) 大地導電率 $(\sigma): \infty$

図 9 大地導電率が $1 \mathrm{mS} / \mathrm{m}(\mathrm{a}), 10 \mathrm{mS} / \mathrm{m}(\mathrm{b}), \infty(\mathrm{c})$ の場合のQ点の誘導雷電王波高值の分岐線路長及 び分岐点位置への依存性（雷撃点位置：G， $\mathrm{d}=100 \mathrm{~m}$ )

Fig. 9 Lightning-induced voltage at Point $Q$ of the overhead wire having a branch, associated with a return stroke at Point $\mathrm{G}$ of $100 \mathrm{~m}$ away.
$2 \mathrm{~km}$ 場合の基幹配電線路中間点（Q点）の誘導雷電圧の分 岐線路長及び分岐点位置への依存性を示す。

分岐線が接続された場合にはQ点の誘導雷電圧は増大し， この傾向は分岐点が Q点に近いほど顕著となる。また，大 地導電率が小さいほよ゙, 分岐線が $\mathrm{Q}$ 点の唀導雷電圧に及ぼ す影響が大きくなっている。これは, 分岐線上で大地導電 率が有限であるために発生する水平電界成分により誘起さ れる進行波の影響が大きいためであり， $\sigma=1 \mathrm{mS} / \mathrm{m}$ で分岐点 が $\mathrm{Q}$ 点 $(\mathrm{xb}=250 \mathrm{~m})$ の場合には, 分岐線路長が長いほど $\mathrm{Q}$ 点の 誘導雷電圧は上昇し, 上昇分は $1 b$ が $500 \mathrm{~m}$ で $40 \%$ 程度, $1 \mathrm{~b}$ が $1 \mathrm{~km}$ で50\%程度となる。

\section{7. 結言}

水平電界を考慮した配電線誘導雷電圧解析手法により, 長さ $500 \mathrm{~m} の$ 基幹配電線に直角に接続された分岐線が，基幹

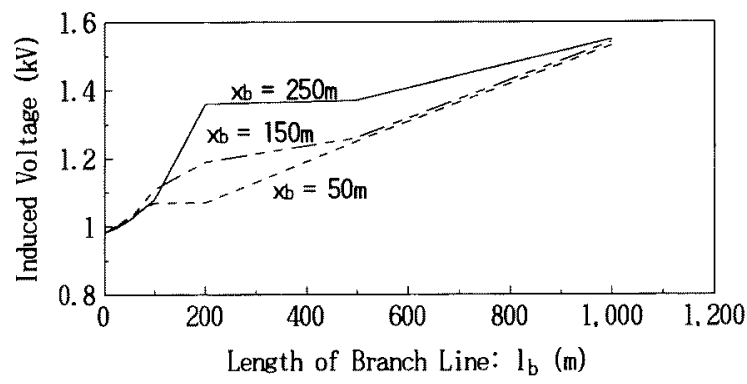

(a) $\sigma=1 \mathrm{mS} / \mathrm{m}$

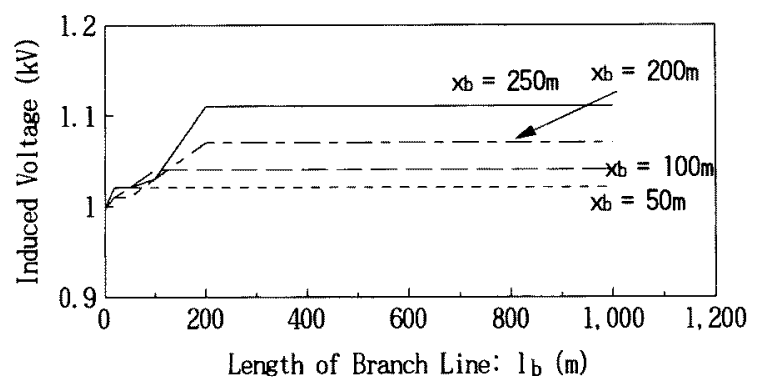

(b) $\sigma=10 \mathrm{mS} / \mathrm{m}$

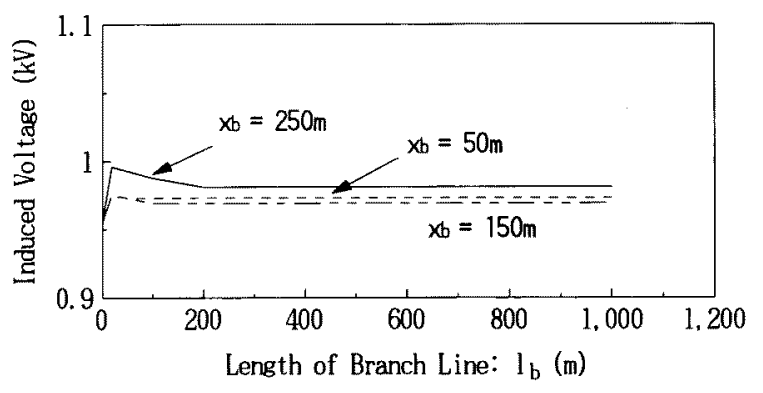

(c) $\sigma=\infty$

図 10 大地導電率が $1 \mathrm{mS} / \mathrm{m}(\mathrm{a}), 10 \mathrm{mS} / \mathrm{m}(\mathrm{b}), \infty$ (c)の場合のQ点の誘導雷電圧波高值の分岐線路 長及び分岐点位置への依存性（雷撃点位置：G， $\mathrm{d}=2 \mathrm{~km}$ )

Fig. 10 Lightning-induced voltage at Point $\mathrm{Q}$ of the overhead wire having a branch, associated with a return stroke at Point $\mathrm{G}$ at the distance of $2 \mathrm{~km}$. 
配電線誘導雷電圧波形に及ぼす影響を検討した結果以下の 知見が得られた。

(1) 分岐線をもつ基幹配電線上に生じる誘導雷電圧の計算結 果の妥当性をモデル実験結果との比較により示した。

（2）分岐線が基幹配電線に接続された場合には，分岐線上で 誘起された進行波が基幹配電線に流入し, 線路端および分 岐点では進行波の反射が発生する。分岐線が基幹配電線誘 導雷電圧に及ぼす影響は, これらの要因により決定される 進行波の大きさと時間遅れに依存する事を明らかにした。

(3) 線路分岐が誘導雷電圧に及ぼす影響は配電線路と雷撃点 の相対的な位置関係に大きく依存する事が明らかになった。 雷撃点位置が基幹配電線の延長方向にある場合には, 分岐 線路長が長いほど分岐線が誘導雷電圧に及ぼす影響は大き く, 雷撃点と線路との距離が $100 \mathrm{~m}$ で分岐線路長が $500 \mathrm{~m}$ 以上 の場合には雷撃点に近い線路終端点の誘導雷電圧は最大 $30 \%$ 程度上昇する。

（4）雷撃点が線路中間点付近にある場合には，分岐線の影響 は，雷撃点が遠方にある方が顕著である。この場合の分岐 線の影響は, 大地導電率と分岐線路長に大きく依存し，大 地導電率が $1 \mathrm{mS} / \mathrm{m}$ で分岐線が $500 \mathrm{~m}$ 以上場合には，線路中間 点の誘導雷電圧は40\% 50\%程度上昇する事が明らかになっ た。

(平成 7 年11月 28 日受付, 同 8 年 1 月 18 日再受付)

\section{文献}

(1) H. Koga, T. Motomitsu, M. Taguchi, "Lightning surge waves induced on overhead lines", Trans. IECE of Japan, E62, 216 223 (1980-4)

(2) M. J. Master and M. A. Uman, "Lightning induced voltages on power lines: Theory", IEEE Trans., PAS-103, 2502 2518（1984-9）

（3）道下幸志, 石井勝, 河村達雄:「大地導電率の配電線誘導 雷電圧波形人の影響」, 電学論 B, 112, 245～251 (平4-3)

（4）今井康友, 道下幸志, 石井勝, 河村達雄 : 「有限な大地 導電率を考慮した多導体系配電線の誘導雷現象解析」, 電学論B, 113, 499 508 (平5-5)

(5) M. Ishii, K. Michishita, Y. Hongo, S. Oguma, "Lightning-induced voltage on an overhead wire dependent on ground conductivity", IEEE Trans. Power Delivery, PWRD-9, 109 118 (1994-1)

(6) A. Zeddam \& P. Degauque, "Current and voltage induced on telecommunication cables by a lightning stroke", Electromagnetics, 7, 541 564 (1987)

（7）道下幸志, 石井勝, 本郷保二：「単導線路に生じる誘導雷 の縮小モデル実験」, 電学論 B $, 114,859$ ８65(平6-9)

（8）道下幸志, 石井勝, 本郷保二：「配電線誘導雷現象に 大地導電率が及ぼす影響のモデル実験一雷道が傾いて いる場合一」, 電学論 B, 115, 964 969 (平7-8)

(9) A. Sakakibara, "Calculation of induced voltages on overhead lines caused by inclined lightning strokes", IEEE Trans. Power Delivery, PWRD-4,
683 693 (1989-1)

(10) 道下幸志, 石井勝：「配電線誘導雷電圧への雷放電路 の傾きの影響一大地が完全導体の場合一」，電学諭 $B, 112,500 \sim 506$ (平4-6)

(11) M. Rubinstein, A. Y. Tzeng, M. A. Uman, P. J Medelius, and E. M. Thomson, "An experimental test of a theory of lightning-induced voltage on an overhead wire", IEEE Trans., EMC-31, 376 383 (1989-9).

（12）道下幸志, 石井勝, 河村達雄:「水平方向電界を考慮し た配電線誘導雷電圧解析法」, 電学論 B, 111, 628 634 (平3-6)

(13) K. A. Norton, "The propagation of radio waves over the surface of the earth and in the upper atmosphere Part II", Proc. IRE, 25, 1203 1236 (1937-9)

(14) A. K. Agrawal, H. J. Price, S. H. Gurbaxiani, "Transient responce of multiconductor transmission lines excited by a nonuniform electromagnetic field", IEEE Trans., EMC-22, 119 129 (1980-5)

(15) 本楖保二, 道下幸志, 石井勝, : 「配電線誘導雷電圧 の分布一大地導電率を考慮した解析一」, 平成 7 年電 気学会電力・エネルギー部門大会(論文 I ), No. 37

道下 幸志（正員）1962年9月24日生。1991年3月東京

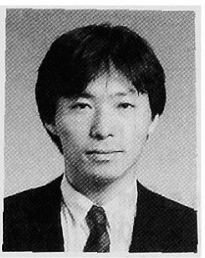
大学大学院工学系研究科電気工学専攻博士 課程修了。工学博士。同年4月静岡大学助 手，1994年4月同助教授，現在に至る。主 として，雷に起因する環境電磁工学に関す る研究に従事。IEEE, AGU Member.

石井勝（正員）1949年3月11日生。1976年3月東京

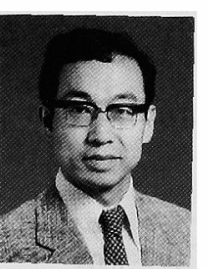
大学大学院工学系研究科博士課程修了。工 学博士。同年4月東京大学助教授, 生産技 術研究所勤務，1992年同教授，現在に至る。 主として系統絶縁, 自然雷, 高電圧現象の 測定に関する研究に従事。1989，1990年度 電気学会東京支部評議員。IEEE Senior Member, AGU Member.

本楖 保二（正員）1957年6月22日生。1981年横浜国

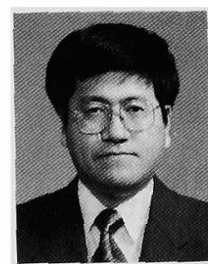
立大学工学部電気工学科卒業。同年4月東 北電力㑣入社。現在, 同社研究開発セン ターに勤務。主として, 配電線雷過電质発 生現象に関寸る研究に従事。 